\title{
A Glance to Infectious Complications During the Course of Chronic Lymphocytic Leukemia: Single Center Experience
}

\section{Kronik Lenfositik Lösemi Sırasında Gelişen Enfeksiyöz Komplikasyonlara Bir Bakış: Tek Merkez Deneyimi}

\author{
Zehra Narlı Özdemir ${ }^{1}$, Berna Nur Karataş ${ }^{2}$, Nur Sima Sekban ${ }^{2}$, Uğur Şahin ${ }^{3}$, Mesude Falay ${ }^{4}$, Funda \\ Ceran ${ }^{1}$, Simten Dağdaş ${ }^{5}$, Gülsüm Özet ${ }^{6}$ \\ ${ }^{1}$ Ankara Şehir Hastanesi, Hematoloji Bilim Dalı, Ankara, Türkiye \\ ${ }^{2}$ Yıldırım Beyazıt Üniversitesi Tıp Fakültesi, Ankara, Türkiye \\ ${ }^{3}$ Medicana Ankara Hastanesi, Hematoloji Bölümü, Ankara, Türkiye \\ ${ }^{4}$ Düzen Laboratuarlar Grubu, Biyokimya Bölümü, Ankara, Türkiye \\ ${ }^{5}$ Sağlık Bilimleri Üniversitesi Tıp Fakültesi, Hematoloji Bölümü, Ankara, Türkiye \\ ${ }^{6}$ Yıldırım Beyazıt Üniversitesi Tıp Fakültesi, Hematoloji Bilim Dalı, Ankara, Türkiye
}

Dergiye Ulaşma Tarihi: 11.05.2020 Dergiye Kabul Tarihi: 02.07.2020 Doi: 10.5505/aot.2020.28199

\section{ÖZET}

GiRiş ve AMAÇ: Enfeksiyonlar kronik lenfositik lösemi (KLL) hastalarında mortalite ve morbiditenin en önemli sebeplerindendir. Bu çalışmada, KLL tanılı hastalarımızın ana klinik ve biyolojik özellikleri ile birlikte hastalığın seyri esnasında gelişen enfeksiyonları özetlemeye çalıştık.

YÖNTEM ve GEREÇLER: Numune Eğitim ve Araştırma Hastanesinde Ocak 2000-Mayıs 2019 tarihleri arasında KLL tanısı alan hastalar retrospektif olarak değerlendirildi

BULGULAR: 204 erkek, 120 kadın toplam 324 hasta çalışmaya dahil edildi. Ortanca yaş 64 (33-91 yıl) saptandı. Takip süresince, \%42,9 ( $\mathrm{n}=139)$ hasta kemoterapi/immunoterapi ile tedavi edildi ve bu hastaların \%17,2' si $(n=57)$ ilk tedaviden sonra nüks etti. Hastalar RAI evresine göre gruplandırıldı. $267(\% 82,4)$ hasta evre 0-2, 57 $(\% 17,6)$ hasta evre 3-4 grubundaydı. Akut ve kronik bakteriyel enfeksiyonlar RAl evre 3-4 olan grupta daha sıktı (\%50,6 ve \%26,6, \%7,0 ve \%0, sırasıyla, $p<0,001)$. CTC-AE grade 4-5 enfeksiyon sıklığı evre 3-4 olan grupta daha yüksekti $(p<0,001)$. Hipogamaglobulinemi ve intravenöz immunglobulin (IVIg) tedavi intiyacı evre 3-4 olan grupta daha sık görüldü (\%45,6 ve \%18,5, \%24,6 ve \%9,7, sırasıyla; $p<0,001$ ve $p=0,002)$. Immuntrombositopeni evre 3-4 olan grupta daha sıktı (\%5,3 ve \%0,7, p=0,03). Ortanca toplam sağ kalım (OS) $97,6+11,8$ ay $(\% 95 \mathrm{Cl}$ $74,4-120,8)$ aydı. Ortanca takip süresi 25,8 ay (1-226,4 ay) saptandı. Evre 3-4 hastalık grubunda OS anlamlı olarak kısa bulundu $(p<0,001)$.

TARTIŞMA ve SONUÇ: KLL hastalarında, enfeksiyonların tipinin ve ciddiyetinin dağılımı evre bağımlı olmakla birlikte, hastalığın her evresinde enfeksiyöz komplikasyonlar sık görülebilir.

Anahtar Kelimeler: Kronik lenfositik lösemi, RAI evresi, enfeksiyonlar, otoimmun sitopeni

\section{ABSTRACT}

INTRODUCTION: Infections are the leading cause of morbidity and mortality in chronic lymphocytic leukemia (CLL) patients. We aim to summarize the main clinical and biological features of CLL patients diagnosed in our center and infections occurred during their disease.

METHODS: Patients diagnosed with CLL in Numune Training and Research Hospital between January 2000 and May 2019, were retrospectively analyzed.

RESULTS: A total of 324 patients, of whom 204 were male and 120 females, were included. The median age was 64 years (33-91 years). During the follow-up, $42.9 \%(n=139)$ were treated with a chemotherapy/immunotherapy and $17.2 \%(n=57)$ of these relapsed after the first line. Patients were analyzed according to Rai stage at diagnosis and were divided into two groups, as stage $0-2$ and stage $3-4$. Stage $0-2$ group involved $82,4 \%(n=267)$ and stage 3-4 group 17,6\% $(n=57)$ of the patients. Acute and chronic bacterial infections were more frequent among patients with stage $3-4$ disease $(50.6 \%$ vs $26.6 \%$ and $7.0 \%$ vs $0 \%$, respectively, $\mathrm{p}<0.001)$. CTC-AE grade $4-5$ infections were higher in the stage $3-4$ group $(\mathrm{p}<0.001)$. Hypogammaglobulinemia and the requirement of intravenous immunoglobulin (IVIg) therapy were more common in grade $3-4$ group $(45.6 \%$ vs $18.5 \%$ and $24.6 \%$ vs $9.7 \%$, respectively; $p<0,001$ and $p=0,002$ ). Immune thrombocytopenia was also more frequent in the stage $3-4$ group (5.3\% vs $0.7 \%, p=0.03)$. Estimated median overall survival (OS) was $97.6+11.8$ (\%95 Cl 74.4-120.8) months. The 
median follow-up time was 25.8 months (1-226.4 months). OS was significantly lower in the stage 3-4 group $(\mathrm{P}<0.001)$.

DISCUSSION AND CONCLUSION: Although, the distribution of type and severity of infections are stage dependent in patients with CLL, frequent infections may occur at every stage of the disease.

Keywords: Chronic lymphocytic leukemia, RAI stage, infections, autoimmune cytopenia

\section{Introduction:}

Chronic lymphocytic leukemia (CLL) is the most frequent lymphoproliferative disease in adults, and it is characterized by its clinical and genetic heterogeneity [1]. Median age at diagnosis is around 70 years [2]. Patients with CLL have progressive immunodeficiency and infections are the leading cause of morbidity and mortality in these patients. The pathogenesis of immune deficiency secondary to CLL is multifactorial including disease- and treatment-related factors. The defect in humoral and cellular immunity and neutropenia with various degree of severity are common in patients with CLL. Neutropenia is related with bone marrow infiltration by the underlying disease. The most obvious and well-known abnormality is hypogammaglobulinemia, which is present in up to $85 \%$ of patients with CLL. In most patients, all immunoglobulin classes are suppressed and the degree of hypogammaglobulinemia depends on the stage and duration of the disease. [3].

It is well-known that patients with CLL have suppression of helper T-cells, imbalances of Tcell subset, diminished $\mathrm{T}$-cell response to proliferative signals. Inverted CD4/CD8 T-cell ratios, with a decreased CD4 $\mathrm{T}$ cells count and high level of cytotoxic CD8 $\mathrm{T}$ cells are also associated with an increased rate of infection in patients with CLL [4-7].

Most infections affect the lower respiratory tract and are usually caused by bacteria such as $S$. pneumoniae, $S$. aureus and $H$. influenzae [8]. Patients with CLL have also a high risk of bloodstream infections. Andersen et al. reported the increased frequency of $S$. pneumoniae and Pseudomonas aeruginosa and the high mortality of candidemia in CLL patients according to results of a longitudinal nation-wide cohort study [9].However, opportunistic infections have been seen sporadically in patients with advanced CLL on treatment [8, 10], Suleman et al. reported disseminated cryptococcal infection in a patient with treatment-naive CLL [11].
The duration of remission and the time between relapse phases in CLL patients have prolonged due to recent advances in CLL treatment. The use of salvage therapies and managing of multiple relapses can lead to cumulative immunosuppression and a higher risk of infections [12]. The introduction of new therapeutic agents in CLL, including the new kinase inhibitors has also changed frequency and epidemiology of infections, that represent a major cause of morbidity and mortality of the disease [13-15]. However, Teh et al. pointed out that treatment with ibrutinib as monotherapy or in combination with chemoimmunotherapies is not associated with additional risk for infection [16], Dotson et al. reported simultaneous infection with disseminated nocardia and pulmonary aspergillus, a rare instance, in a patient receiving ibrutinib for CLL [17].

Autoimmune cytopenia (AIC) occur in approximately $4-10 \%$ patients with CLL . The precise incidence of AIC may be difficult to determine because these can come before CLL diagnosis and present at any time of disease $[18,19]$. AIC-related morbidity may be significant; furthermore, the risk of infection increases, and pre-existing infections may deteriorate due to immunosuppressive drugs [20].

The aim of this study is to evaluate the incidence of infectious and immune complications in patients with CLL diagnosed and/or treated in one center according to the RAI stage of disease.

\section{Materials and methods:}

We retrospectively analyzed clinical features, treatment outcomes and infectious complications of patients diagnosed with CLL between January 2000 and June 2019. The medical records of Ankara Numune Training and Research Hospital were retrospectively reviewed in terms of age, sex, cytogenetic data, type and grade of infectious complications, comorbidities, the presence of hypogammaglobulinemia, hemolytic anemia and immune thrombocytopenia, the need for 
intravenous immunoglobulin (IVIg) and the presence of secondary malignancies and Richter transformation. Patients $\geq 18$ years were included in the study. Cytogenetic data including deletion $13 p$ (del 13p), deletion $17 p$ (del 17p) and deletion 11q (del 11q) were analyzed with fluorescent in situ hybridization (FISH). Severity of infections were graded according to Common Terminology Criteria for Adverse Events (CTCAE) v5.0. In addition to the symptoms and findings of patients, computed tomography and X-RAY were used to identify and classify lower respiratory tract infections including invasive fungal infections. The galactomannan test was considered positive, when an optical density index (ODI) of 0.5 or higher.

\section{Statistical Methods:}

SPSS version 22 was used for statistical analysis and overall survival was assessed by of Kaplan-Meier method. Multivariate analyzes were performed via a Coxproportional hazards model. A p value of < 0.05 was considered statistically significant.

\section{Results:}

A total of 324 patients, of whom 204 (63\%) were male and $120(37 \%)$ females, were included. The median age was 64 years (33-91 years) (Table 1). Patients were analyzed according to Rai stage at diagnosis and were divided into two groups, as stage 0-2 and stage 3-4. Stage 0-2 group involved $82.4 \%(n=267)$ and stage 3-4 group $17.6 \% \quad(n=57)$ of the patients (Table 2).

During the follow-up, $42.9 \%(n=139)$ were treated with a chemotherapy/immunotherapy regimen. Fifty- one $(89.5 \%)$ patients who had stage 3-4 CLL, needed treatment in follow up period. $40.4 \%(n=24)$ of these patients relapsed after first-line treatment. Eighty-eight $(33.0 \%)$ patients who were in stage 0-2 group treated in follow up period and $12.7 \% \quad(n=34)$ of them were relapsed after first-line therapy. Need of treatment and relapse after first line-therapy were significantly higher in the stage 3-4 CLL group $(\mathrm{p}=<0,001$ and $\mathrm{p}=<0,001$, respectively).

As first-line treatment, fludarabine based regimens were given to $35(25.2 \%)$ of 139 patients,CVPchemotherapy regimen (cyclophosphamide750 $\mathrm{mg} / \mathrm{m}^{2}$ day 1 , vincristine1.4 $\mathrm{mg} / \mathrm{m}^{2}$ day1, methylprednisolone $100 \mathrm{mg} / \mathrm{m}^{2}$ day $\left.1-5\right)$ was given to $56(40.3 \%)$ patients, chlorambucil was given to $40(28.8 \%)$ patients, bendamustine was given to $3(2.2 \%)$ patients and other agents were given to $5(3.5 \%)$ patients. Rituximab was added to the treatment protocol of 45 (32.4\%) patients receiving first-line therapy and obinutuzumab was added to the treatment of $1(0.7 \%)$ patient. The patients who were treated with fludarabine based regimens as first line therapy, were younger than other patients with median age 55 years (39-71 years). Median age of patients who were treated with CVP and chlorambucil were 65 years (59-82 years) and 64 years (57-91 years), respectively. $17.2 \%(n=57)$ of these patients relapsed after the first line treatment. Relapse / refractory CLL patients were treated with fludarabine, chlorambucil, CVP or bendamustine considering first-line treatments. 1 (1.8\%) patient were treated with alemtuzumab as second-line therapy and $3(5.3 \%)$ patients who had received more than 2 lines of treatment were treated with ibrutinib.

The groups were all similar in terms of age, sex, comorbidities, cytogenetic features, the presence of hemolytic anemia, viral infections (upper respiratory tract, herpes simplex, herpes zoster, chronic active hepatitis $B$ virus $(H B V)$ and cytomegalovirus (CMV)),fungal infections (superficial and invasive), secondary malignancies (solid tumors, hematologic malignancies and skin tumors) and Richter transformation (Table 2). Ninety-eight $(30.2 \%)$ of 324 patients were tested for del $13 q$ with FISH and $43.9 \%(n=43)$ of them had 13q deletion. Stage 0-2 and stage 3-4 CLL groups were similar about presence of del $13 \mathrm{q} \quad(13.9 \%$ vs $10.5 \%$ respectively; $\mathrm{p}=0.59)$. One hundred eighteen $(36.4 \%)$ of 324 patients were screened for del $17 \mathrm{p}$ and $7.6 \%$ $(n=9)$ of 118 patients were positive for del17p with FISH. There was no significant difference between stage 0-2 and 3-4 groups about presence of del $17 \mathrm{p}$ (3\% vs $1.8 \%$ respectively; $\mathrm{p}=0.80)$. Ninety-four (29\%) patients had del $11 \mathrm{q}$ testing with FISH and $11.7 \%(n=11)$ of these patients were positive for del 11q. There was no difference between two groups in terms of del 11q (3.4\% vs 3.5\%, respectively; $\mathrm{p}=0.87)$ (Table 2).

Fifty-six (17.3\%) of 324 patients had viral infections including 66\% $(\mathrm{n}=37)$ upper 
respiratory tract infections, $7.2 \%(\mathrm{n}=4)$ herpes simplex, $16 \%(n=9)$ herpes zoster, $7.2 \%(n=4)$ chronic active HBV and 3.6\% ( $\mathrm{n}=2)$ CMV. There was no significant difference between stage 0-2 and 3-4 groups in terms of viral infectious $(\mathrm{p}=0.12)$ (Table 2).

Table 1. General features of patients with CLL and infectious complications

\begin{tabular}{|c|c|c|}
\hline & $\mathrm{N}=324$ & $\%$ \\
\hline \multicolumn{3}{|l|}{ Gender } \\
\hline Male & 204 & $63 \%$ \\
\hline Female & 120 & $37 \%$ \\
\hline \multicolumn{3}{|l|}{ Age } \\
\hline \multicolumn{3}{|l|}{64 years (33-91 years) } \\
\hline Comorbidities & 184 & $56.8 \%$ \\
\hline None & 118 & $36.4 \%$ \\
\hline Metabolic and /or cardiopulmonary disease & 14 & $4.3 \%$ \\
\hline Solid tumor & 6 & $1.9 \%$ \\
\hline Rheumatic disease & 2 & $0.6 \%$ \\
\hline \multicolumn{3}{|l|}{ Unknown } \\
\hline \multicolumn{3}{|l|}{ RAI Stage } \\
\hline 0 & 95 & $29.3 \%$ \\
\hline I & 103 & $31.8 \%$ \\
\hline II & 69 & $21.3 \%$ \\
\hline III & 20 & $6.2 \%$ \\
\hline IV & 37 & $11.4 \%$ \\
\hline \multicolumn{3}{|l|}{ Treatment } \\
\hline None & 185 & $57.1 \%$ \\
\hline $1^{\text {st }}$ line therapy & 139 & $42.9 \%$ \\
\hline$\geq 2$ line therapy & 57 & $17.2 \%$ \\
\hline \multicolumn{3}{|l|}{ Bacterial infections } \\
\hline None & 220 & $67.9 \%$ \\
\hline Bacterial infections & 104 & $32.1 \%$ \\
\hline acute & 100 & $96.2 \%$ \\
\hline chronic & 4 & $3.8 \%$ \\
\hline \multicolumn{3}{|l|}{ Viral infections } \\
\hline None & 268 & $82.7 \%$ \\
\hline Viral infections & 56 & $17.3 \%$ \\
\hline upper respiratory tract & 37 & $66 \%$ \\
\hline herpes simplex & 4 & $7.2 \%$ \\
\hline herpes zoster & 9 & $16 \%$ \\
\hline chronic active HBV & 4 & $7.2 \%$ \\
\hline $\mathrm{CMV}$ & 2 & $3.6 \%$ \\
\hline \multicolumn{3}{|l|}{ Fungal infections } \\
\hline None & 317 & $97.8 \%$ \\
\hline Fungal infections & 7 & $2.2 \%$ \\
\hline superficial & 3 & $42.9 \%$ \\
\hline invasive & 4 & $57.1 \%$ \\
\hline
\end{tabular}


Table 2. General characteristics of patients according to disease stage

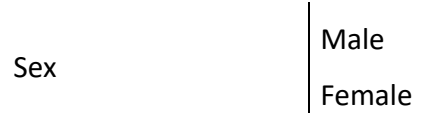

Median age at diagnosis (min-max)

\begin{tabular}{l|l} 
Comorbidities & Metabolic and /or \\
cardiopulmonary disease \\
Solid tumor \\
Rheumatic disease
\end{tabular}

Patients treated in follow-up

Recurrence after first-line treatment

HBsAg (+)

Anti-HBs (+)

Anti-HBc (+)

Anti-HCV (+)

Anti-HIV (+)

del13q

del17p

\begin{tabular}{l|l} 
Hemolytic anemia & Absent \\
Immune & Present \\
Absent \\
thrombocytopenia & Present
\end{tabular}

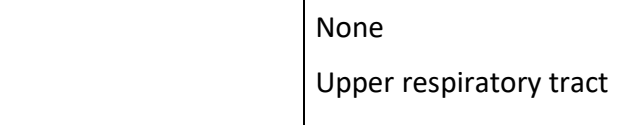

Viral infections

\begin{tabular}{l|l} 
& Herpes zoster \\
& Chronic active HBV \\
CMV \\
Bacterial infections & None \\
Acute \\
Chronic (tbc. brucella) \\
Fungal infections & $\begin{array}{l}\text { None } \\
\text { Superficial }\end{array}$
\end{tabular}

$(\mathrm{N}=\mathbf{2 6 7})$

$82.4(\%)$

$165(61.8)$

$102(98.2)$

$64(33-91)$

$146(54,7)$

$103(38,6)$

$12(4,5)$

$6(2,2)$

$88(33,0)$

$34(12,7)$

$19(7.1)$

13 (4.9)

$20(7.5)$

$1(0.4)$

47 (17.6)

37 (13.9)

91 (34.1)

8 (3.0)

$70(26.2)$

9 (3.4)

243 (91.0)

20 (7.5)

261 (97.8)

$2(0.7)$

226 (84.6)

27 (10.1)

$2(0.7)$

6 (2.2)

4 (1.5)

2 (0.7)

196 (73.4)

71 (26.6)

-

262 (98.1)

3 (1.1)
Stage 3-4

( $N=57)$

17.6 (\%)

39 (68.4)

18 (31.6)

64 (43-79)

0,35

0,92

$38(69,1)$

$15(27,3)$

0,21

$2(3,6)$

$51(89,5)$

$<0,001$

$23(40,4)$

2 (3.5)

$<0,001$

0.32

0.90

0.90

0.64

$3(5.3)$

4 (7.0)

-

0.59

$6(10.5)$

18 (31.6)

1 (1.8)

0.80

13 (22.8)

2 (3.5)

49 (86.0)

8 (14.0)

54 (94.7)

3 (5.3)

42 (73.7)

10 (17.5)

2 (3.5)

3 (5.3)

0.12

3.

0.19

0.03

-

24 (42.1)

29 (50.9)

$<0.001$

4 (7.0)

55 (96.5) 


\begin{tabular}{|c|c|c|c|c|}
\hline & Invasive & $2(0.7)$ & $2(3.5)$ & \\
\hline & 0 & $169(63.3)$ & $21(36.8)$ & \\
\hline & 1 & $13(4.9)$ & $3(5.3)$ & \\
\hline Infection grade & 2 & $52(19.5)$ & $15(26.3)$ & $<0.001$ \\
\hline (CTC-AE) & 3 & $19(7.1)$ & $4(7.0)$ & \\
\hline & 4 & $7(2.6)$ & $9(15.8)$ & \\
\hline & 5 & $7(2.6)$ & $5(8.8)$ & \\
\hline Hypogammaglobulinemi & & $49(18.4)$ & $26(45.6)$ & $<0.001$ \\
\hline IVIg replacement & & $26(9.7)$ & $14(24.6)$ & 0.002 \\
\hline & Solid tumor & $11(37.9)$ & $1(12.5)$ & \\
\hline Secondary malignancies & Hematologic malignancies & $4(13.8)$ & $4(50.0)$ & 0.08 \\
\hline & Skin tumors & $6(20.7)$ & - & \\
\hline Richter transformation & & $3(1.1)$ & $2(3.5)$ & 0.19 \\
\hline
\end{tabular}

Bacterial infectious occurred in 104/324 (32.1\%) patients during their disease course, $96.2 \%(n=100)$ of which were acute bacterial infections and $3.8 \% \quad(n=4)$ of which were chronic. Acute and chronic bacterial (brucella, tuberculosis, etc.) infections were more common among patients with stage 3-4 disease $(50.6 \%$ vs $26.6 \%$ and $7.0 \%$ vs $0 \%$, respectively; $\mathrm{p}<0.001$ ) (Table 2).

Fifty-nine $(55 \%)$ patients had acute bacterial infections in lower respiratory truck, 17 (17\%) patients had bacterial infections in urinary system, 9 (\%9) patients had in upper respiratory truck, 9 (9\%) patients had blood stream infections, $6(6 \%)$ patients had bacterial infections in oral cavity involving teeth and gums, , 2(\%2) patients had skin infections with bacteria and $2(\% 2)$ patients had others.

Fungal infections occurred in 7/324 (2.2\%) patients during their disease course, $42.9 \%$ $(n=3)$ of which were superficial fungal infections and $57.1 \% \quad(n=4)$ of which were invasive fungal infections. There was no significant difference between stage 0-2 and 34 groups in terms of fungal infections $(\mathrm{p}=0.17)$ (Table 2). However, CTC-AE grade 4-5 infections were higher in the stage 3-4 group $(15.8 \%$ vs $2.6 \%$ and $8.8 \%$ vs $2.6 \%$, respectively; $\quad(\mathrm{p}<0.001$ and $\mathrm{p}<0.001)$. Hypogammaglobulinemia and the requirement of IVIg therapy were more common in grade $3-4$ group $(45.6 \%$ vs $18.5 \%$ and $24.6 \%$ vs $9.7 \%$, respectively; $\mathrm{p}<0,001$ and $\mathrm{p}=0,002$ ) (Table 2).

Adress for correspondence: Üniversiteler, Bilkent Blv. No: 1, Çankaya 06800 Ankara - Türkiye e-mail: zehranarli@hotmail.com

Available at www.actaoncologicaturcica.con

Copyright $\odot$ Ankara Onkoloji Hastanesi
Autoimmune hemolytic anemia (AIHA) was observed in $28 / 324$ (8.7\%) patients during their disease course and frequency of hemolytic anemia was similar between two groups $(7.5 \%$ and $14 \%$, respectively; $\mathrm{p}=0.19)$ Immune thrombocytopenia occurred in 5/324 (1.6\%) of patients with CLL and was significantly more frequent in the stage $3-4$ group (5.3\% vs $0.7 \%$, $\mathrm{p}=0.03)$ (Table 2).

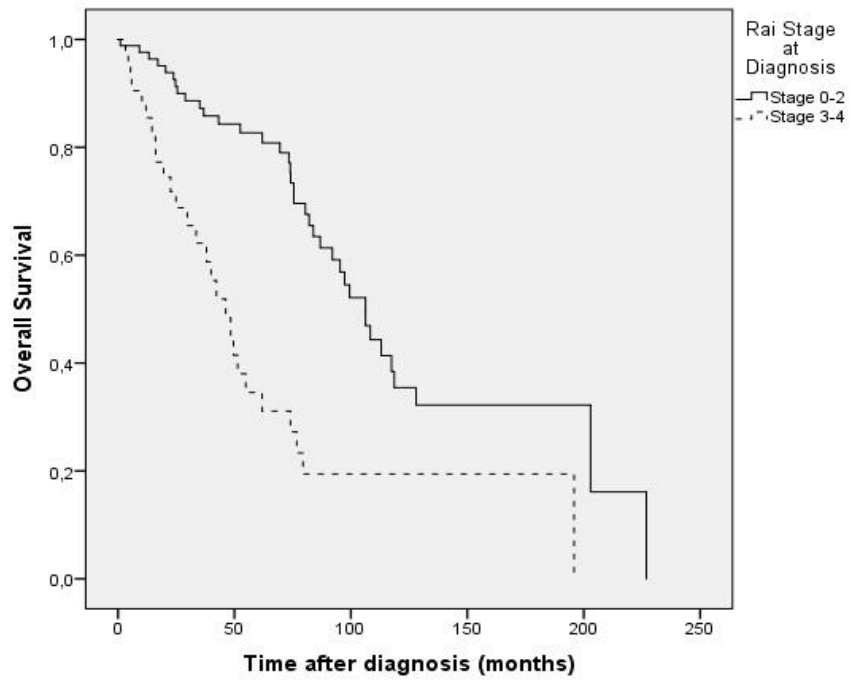

Figure1: Relationshipbetween RAI stage and overall survival

Secondary malignancies were found in 26 (8\%) patients during their follow up period. $12 / 26(46.2 \%)$ patients had solid tumors, 8 $(30.8 \%)$ patients had hematological 
malignancies and $6(23 \%)$ patients had skin tumors. There was no significant difference between stage 0-2 and 3-4 groups in terms of secondary malignancies $(\mathrm{p}=0.08)$. Richter transformation occurred only in $5(1.5 \%)$ patients and two groups were similar in terms of Richter transformation (1.1\% vs \%3.5 respectively; $\mathrm{p}=0.19$ ) (Table 2 ).

Estimated median overall survival (OS) was 97.6+11.8 (\%95 CI 74.4-120.8) months. The median follow-up time was 25.8 months (1226.4 months). OS was significantly lower in the stage 3-4 group than stage 0-2 group (42 vs 107.5 months; respectively, $\mathrm{P}<0.001$ ) (Figure 1). Non-relapse mortality (NRM) was similar in two groups. A multivariate analysis involving Rai stage at diagnosis, immune thrombocytopenia and the presence of relapse revealed that Rai stage at diagnosis and relapse were independent factors affecting OS $(p<0.001$ and $p=0.09$, respectively)

\section{Discussion:}

Survival of CLL patients in previous studies is strongly dependent on disease stage according to the classifications of Binet [21] and RAI [22]. In the last decades, the treatment of CLL has significantly improved with the introduction of novel agents such as purine analogs, new monoclonal antibodies and BCR signaling inhibitors. Advances in CLL treatment have led to significant improvement in treatment success but have also brought a change in the spectrum of infections. Infections are a cause of concern not only in patients under treatment for CLL, but also in patients with untreated CLL. Nowadays, we have a better knowledge about the incidence of these infections based on previous studies. We aim to evaluate the incidence of a variety of infectious and immune complications in patients with CLL regarding the RAI stage of disease in this study.

Weide at al. reported the analysis of 724 CLLoutpatients in routine care from 1995 to 2017. $\% 46$ of patients received treatment during the evaluation period and in patients who never needed any CLL therapy $10 \%$ formally died due to CLL, $54.5 \%$ of them due to infections and $45.5 \%$ of them due to second cancer [23]. In our study, $42.9 \%$ of patients needed treatment and $17.2 \%$ of these patients relapsed after first line treatment and received second line therapy. \%2.2 of our patients died due to infections and both CTC-AE grade 4 and 5 infections were found more frequent in stage group 3-4 patients. As expected, we found that requirement of treatment for CLL and relapse after first line treatment were higher in patients with stage 3-4 CLL compared with stage 0-2 group.

Andersen et al. reported the results of a longitudinal nation-wide cohort study in which a total of 3677 and 1020 patients with CLL were included as treatment-naive and treated patients, respectively. They identified 145 cases of Gram-positive bacteremia, 166cases of Gram-negative microorganisms and 6 episodes of candidemia of $83 \%$ whichwere fatal within 30 days. Streptococcus pneumoniae accounted for $22 \%$ of cases, while Staphylococcus aureus was found in $21 \%$ of patients and Escherichia coli in $46 \%$ of cases.[9]We retrospectively analyzed frequency of bacterial, viral and fungal infections and found in $32.1 \%, 17.3 \%$ and $2.2 \%$ of our study population, respectively. Bacterial infections were most frequent infection type in our study and both acute and chronic bacterial infections were more common in stage 3-4 patients' group $(<0.001)$. In our series, the most affected area with bacterial infections was lower respiratory truck followed by urinary system, blood stream infections, upper respiratory tract, teeth and gums, skin and others, respectively. There was no significantly difference in terms of viral and fungal infections between stage 0-2 and stage 3-4 group. We suggested that the distribution of type and severity of infections are stage dependent in patient with CLL.

In our study CVP including cyclophosphamide, vincristine and prednisolone was the most widely used regimen followed by fludarabine, chlorambucil and bendamustine. Rituximab was added to the treatment protocol in $32.4 \%$ of patients receiving first-line therapy and obinutuzumab was added to the treatment in $0.7 \%$ of patients. Although chemotherapeutics such as alkylating agents, purine analogues and monoclonal antibodies have dramatically improved CLL outcomes, the predisposition to serious infections can result in significant morbidity, $-80 \%$ of CLL patients will have a significant infection over the course of their disease [16]. 
Korona-Glowniak et al. reported a significantly higher frequency of $S$. aureus and Gramnegative bacilli (GNB) colonization in CLL patients compared with healthy volunteers. They observed pneumonia and bronchitis only in patients after implementation of treatment that increased the risk of infections more than 50 times [24]. In our study we observed acute bacterial infections including pneumonia and bronchitis were more common in patients with stage 3-4 CLL. Requirement of treatment and relapse after first line therapy were higher in stage 3-4 group compared with patients with stage 0-2 CLL.

Advances in CLL therapy, supportive care and infection prophylaxis have led to significant improvement in survival rates. Weide et al. suggested that the improvement in survival of patients with CLL in routine care, was strongly associated with active disease, disease stage, performance status and whether therapy included an anti-CD20 monoclonal antibody [23]. In our study, estimated median OS was 97.6 \pm 11.8 (\%95 CI 74.4-120.8) months. OS was significantly lower in the stage 3-4 group $(\mathrm{P}<0.001)$ and NRM was similar in two groups. The fact that NRM was similar in both groups may be due to the frequent occurrence of severe infections at every stage of the disease.A multivariate analysis involving Rai stage at diagnosis, immune thrombocytopenia and the presence of relapse revealed that Rai stage at diagnosis and relapse were independent factors affecting OS ( $\mathrm{p}<0.001$ and $\mathrm{p}=0.09$, respectively). Although, there was no significant effect on OS, immune thrombocytopenia was more common in patients with stage 3-4 CLL.

Autoimmune hemolytic anemia (AIHA) is the most common autoimmune cytopenia that occurs in CLL with an incidence of $5-10 \%$, followed by immune thrombocytopenia in 1$2 \%$ of patients[20, 25]. In our series AIHA was seen in $8.7 \%$ of patients and frequency of hemolytic anemia was similar between two groups. Immune thrombocytopenia was observed in $1.6 \%$ of patients. The frequency of immune thrombocytopenia was higher in the stage 3-4 group however, the presence of immune thrombocytopenia had no effect on OS.

Previous studies proved that patients with CLL are prone to occurrence of secondary malignancies including solid organ tumors and hematological malignancies[26, 27]. Kumar et al. reported the higher risk for both solid (SIR $1.15 ; 95 \%$ CI:1.12-1.18) and hematological malignancies (SIR 1.61; 95\% CI:1.5-1.73) in patients with CLL [28].Tsimberidou et al. observed that $11.2 \%$ of CLL patients developed other malignancies during the follow-up periodincluding skin $(30 \%)$, prostate (13\%), breast (9\%), melanoma (8\%), lymphoma $(8 \%)$, gastrointestinal $(9 \%)$, lung (6\%), and other cancers (17\%)[26].In our study, secondary malignancies were found in $8 \%$ of patients during their follow up period. $46.2 \%$ of patients had solid tumors, $30.8 \%$ of patients had hematological malignancies and $23 \%$ of patients had skin tumors. Richter transformation occurred only in $1.5 \%$ of our patients and two groups were similar in terms of secondary malignancies and Richter transformation.With a median follow-up of 3 to 12 years, the prevalence of Richter transformation varied from $1 \%$ to $10.7 \%$ in patients who received chemotherapy or chemoimmunotherapy prior the era of novel agents[29].

Since our study was a retrospective analysis covering nearly 20 years, it had limitations compared with a prospective study. The major limitations were as follows: A lack of data about subgroups of bacterial infections such as gram positive / negative bacteria's and subgroups of particularly invasive fungal infections such as Aspergillus, Candida or Mucor species, etc.

However, we suggested that our study can contribute to the literature as it includes a large number of patients and provides real-life data.It is important to obtain local data as it may differ from the global in infectious diseases. This is the first study which highlights the infectious complications in CLL patients in our country.

\section{Conclusion}

In our study, need of treatment in follow up period, relapse after first line treatment, bacterial infections, any kind of CT-CAE grade 4-5 infections hypogammaglobulinemia, requirement of IVIg therapy and immune thrombocytopenia were observed more common in patients with RAI stage 3-4 CLL. A multivariate analysis involving Rai stage at 
diagnosis, immune thrombocytopenia and the presence of relapse revealed that Rai stage at diagnosis and relapse were independent factors affecting OS. We suggested that the variety and severity of infections are stage dependent in patient with CLL. Non-relapse mortality was similar in both groups, which may be associated with the frequent occurrence of infections at each stage of the disease.

\section{Acknowledgement}

On behalf of all authors, there was no conflict of interest.

Informed consent was taken.

Ethical approval was taken.

\section{References:}

1. Dohner, H., et al., Genomic aberrations and survival in chronic lymphocytic leukemia. $\mathrm{N}$ Engl J Med, 2000. 343(26): p. 1910-6.

2. Sant, M., et al., Incidence of hematologic malignancies in Europe by morphologic subtype: results of the HAEMACARE project. Blood, 2010. 116(19): p. 3724-34.

3. Hamblin, A.D. and T.J. Hamblin, The immunodeficiency of chronic lymphocytic leukaemia. Br Med Bull, 2008. 87: p. 49-62.

4. Itala, M., et al., Infections and serum $\operatorname{Ig} G$ levels in patients with chronic lymphocytic leukemia. Eur J Haematol, 1992. 48(5): p. 26670.

5. Ravandi, F. and S. O'Brien, Immune defects in patients with chronic lymphocytic leukemia. Cancer Immunol Immunother, 2006. 55(2): p. 197-209.

6. Gonzalez-Rodriguez, A.P., et al., Prognostic significance of CD8 and CD4 $T$ cells in chronic lymphocytic leukemia. Leuk Lymphoma, 2010. 51(10): p. 1829-36.

7. Allahmoradi, E., et al., CD4+ T Cells are Exhausted and Show Functional Defects in Chronic Lymphocytic Leukemia. Iran $\mathbf{J}$ Immunol, 2017. 14(4): p. 257-269.

8. Dearden, C., Disease-specific complications of chronic lymphocytic leukemia. Hematology Am Soc Hematol Educ Program, 2008: p. 4506.

9. Andersen, M.A., et al., Epidemiology of bloodstream infections in patients with chronic lymphocytic leukemia: a longitudinal nationwide cohort study. Leukemia, 2019. 33(3): p. 662-670.
10. Morrison, V.A., Infectious complications in patients with chronic lymphocytic leukemia: pathogenesis, spectrum of infection, and approaches to prophylaxis. Clin Lymphoma Myeloma, 2009. 9(5): p. 365-70.

11. Suleman, A., et al., Disseminated cryptococcal infection in a patient with treatment-naive chronic lymphocytic leukemia (CLL). IDCases, 2019. 17: p. e00566.

12. Friman, V., et al., Secondary immunodeficiency in lymphoproliferative malignancies. Hematol Oncol, 2016. 34(3): p. 121-32.

13. Zinzani, P.L., et al., Infection control in patients treated for chronic lymphocytic leukemia with ibrutinib or idelalisib: recommendations from Italian society of hematology. Leuk Res, 2019. 81: p. 88-94.

14. Ruchlemer, R., et al., Ibrutinib-associated invasive fungal diseases in patients with chronic lymphocytic leukaemia and nonHodgkin lymphoma: An observational study. Mycoses, 2019.

15. Koehler, A.B., P. Vijayvargiya, and W. Ding, Probable Invasive Pulmonary Cryptococcosis and Possible Cryptococcal Empyema in CLL Treated With Frontline Ibrutinib. Mayo Clin Proc, 2019. 94(5): p. 915-917.

16. Teh, B.W., et al., Infections in patients with chronic lymphocytic leukaemia: Mitigating risk in the era of targeted therapies. Blood Rev, 2018. 32(6): p. 499-507.

17. Dotson, J., et al., A Rare Instance of Simultaneous Infection with Disseminated Nocardia and Pulmonary Aspergillus in a Patient Receiving Treatment with Ibrutinib for Chronic Lymphocytic Leukemia. Cureus, 2018. 10(10): p. e3427.

18. Moreno, C., et al., Autoimmune cytopenia in chronic lymphocytic leukemia: prevalence, clinical associations, and prognostic significance. Blood, 2010. 116(23): p. 4771-6.

19. Tsang, M. and S.A. Parikh, A Concise Review of Autoimmune Cytopenias in Chronic Lymphocytic Leukemia. Curr Hematol Malig Rep, 2017. 12(1): p. 29-38.

20. De Back, T.R., A.P. Kater, and S.H. Tonino, Autoimmune cytopenias in chronic lymphocytic leukemia: a concise review and treatment recommendations. Expert Rev Hematol, 2018. 11(8): p. 613-624.

21. Binet, J.L., et al., A new prognostic classification of chronic lymphocytic leukemia 
derived from a multivariate survival analysis. Cancer, 1981. 48(1): p. 198-206.

22. Rai KR, Sawitsky A, Cronkite EP, Chanana $A D$, Levy RN, Pasternack BS. Clinical staging of chronic lymphocytic leukemia. Blood. 1975;46(2):219-234. Blood, 2016. 128(17): p. 2109.

23. Weide, R., et al., Survival improvement of patients with chronic lymphocytic leukemia (CLL) in routine care 1995-2017. Leuk Lymphoma, 2019: p. 1-10.

24. Korona-Glowniak, I., et al., Bacterial Colonization in Patients with Chronic Lymphocytic Leukemia and Factors Associated with Infections and Colonization. J Clin Med, 2019. 8(6).

25. Hodgson, K., et al., Chronic lymphocytic leukemia and autoimmunity: a systematic review. Haematologica, 2011. 96(5): p. 752-61.

26. Tsimberidou, A.M., et al., Other malignancies in chronic lymphocytic leukemia/small lymphocytic lymphoma. J Clin Oncol, 2009. 27(6): p. 904-10.

27. Kyle, G., Chronic lymphocytic leukaemia and secondary skin malignancies. Br J Nurs, 2017. 26(18): p. 1026-1032.

28. Kumar, V., et al., Trends in the risk of second primary malignancies among survivors of chronic lymphocytic leukemia. Blood Cancer J, 2019. 9(10): p. 75.

29. Ding, W., Richter transformation in the era of novel agents. Hematology Am Soc Hematol Educ Program, 2018. 2018(1): p. 256-263. 